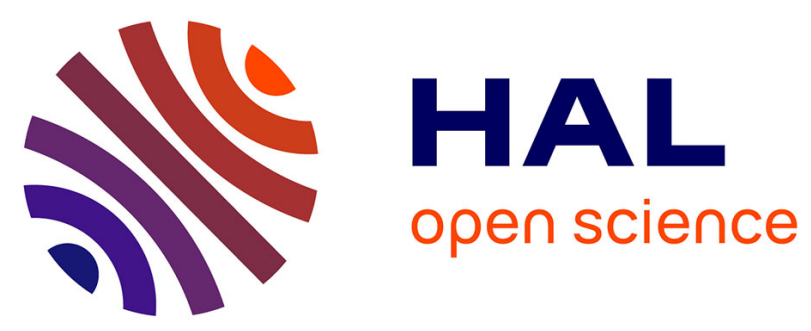

\title{
Simulating the effects of spatial configurations of agricultural ditch drainage networks on surface runoff from agricultural catchments
}

Florent Levavasseur, Jean-Stéphane Bailly, Philippe Lagacherie, François Colin, Michael Rabotin

\section{To cite this version:}

Florent Levavasseur, Jean-Stéphane Bailly, Philippe Lagacherie, François Colin, Michael Rabotin. Simulating the effects of spatial configurations of agricultural ditch drainage networks on surface runoff from agricultural catchments. Hydrological Processes, 2012, 26 (22), p. 3393 - p. 3404. 10.1002/hyp.8422 . hal-00794108

\section{HAL Id: hal-00794108 \\ https://hal.science/hal-00794108}

Submitted on 25 Feb 2013

HAL is a multi-disciplinary open access archive for the deposit and dissemination of scientific research documents, whether they are published or not. The documents may come from teaching and research institutions in France or abroad, or from public or private research centers.
L'archive ouverte pluridisciplinaire HAL, est destinée au dépôt et à la diffusion de documents scientifiques de niveau recherche, publiés ou non, émanant des établissements d'enseignement et de recherche français ou étrangers, des laboratoires publics ou privés. 

networks on surface runoff from agricultural catchments

${ }^{a}$ UMR 1221 LISAH F-34035, INRA, Montpellier, France.

${ }^{\mathrm{b}}$ UMR 1221 LISAH F-34035, AgroParisTech, Montpellier, France.

' UMR TETIS F-34093, AgroParisTech, Montpellier, France.

9 Abstract

10 The study of runoff is a crucial issue because it is closely related to flooding, water quality

11 and erosion. In cultivated catchments, agricultural ditch drainage networks are known to

12 influence runoff. As anthropogenic elements, agricultural ditch drainage networks can

13 therefore be altered to better manage surface runoff in cultivated catchments. However, the

14 relationship between the spatial configuration, i.e., the density and the topology, of

15 agricultural ditch drainage networks and surface runoff in cultivated catchments is not

16 understood. We studied this relationship by using a random network simulator that was

17 coupled to a distributed hydrological model. The simulations explored a large variety of

18 spatial configurations corresponding to a thousand stochastic agricultural ditch drainage

19 networks on a $6.4 \mathrm{~km}^{2}$ Mediterranean cultivated catchment. Next, several distributed

20 hydrological functions were used to compute water flow-paths and runoff for each simulation.

21 The results showed that (i) denser networks increased the drained volume and the peak

22 discharge and decreased hillslopes runoff, (ii) greater network density did not affect the

23 surface runoff any further above a given network density, (iii) the correlation between

24 network density and runoff was weaker for small subcatchments $\left(<2 \mathrm{~km}^{2}\right)$ where the

25 variability in the drained area that resulted from changes in agricultural ditch drainage 
Author-produced version of the article published in Hydrological Processes, 2012, 26(22), 3393-3404.

The original publication is available at http://onlinelibrary.wiley.com

DOI:10.1002/hyp.8422

26 networks increased the variability of runoff and (iv) the actual agricultural ditch drainage

27 network appeared to be well optimized for managing runoff as compared with the simulated

28 networks. Finally, our results highlighted the role of agricultural ditch drainage networks in

29 intercepting and decreasing overland flow on hillslopes and increasing runoff in drainage

30 networks.

32 Keywords

33 Agricultural ditch drainage network, cultivated catchments, stochastic simulations,

34 hydrological modeling, runoff.

\section{Introduction}

36 Hedges, ditches, terrace fronts, embankments, grass strips and roads are common linear

37 features of cultivated landscapes (Figure 1).

Figure 1

39 The functional importance of these features has been emphasized in various contexts and

40 biophysical processes. In ecology, they provide valuable habitats, enhance connectivity within

41 landscapes and can serve as habitats for rare species (Forman \& Baudry, 1984; Herzon \&

42 Helenius, 2008; Watson \& Ormerod, 2004; Pita et al., 2006). Linear features affect soil

43 redistribution as well, especially terraces that attenuate slopes, facilitate agriculture and limit

44 long-term soil loss (Bevan \& Conolly, 2011; Paroissien et al., 2010). By favoring water

45 infiltration, they play a role in groundwater hydrology (Dages et al., 2009). Linear features

46 also alter overland flow paths (Duke et al., 2006; Gascuel-Odoux et al., 2011). They can force

47 water to not follow the steepest slope, but they can also concentrate runoff along the steepest

48 slope. 
Author-produced version of the article published in Hydrological Processes, 2012, 26(22), 3393-3404.

The original publication is available at http://onlinelibrary.wiley.com

DOI:10.1002/hyp.8422

49 When focusing on the impacts of agricultural ditch drainage networks, four roles are

50 commonly considered: the interception of overland flow on hillslopes, the drainage of

51 groundwater and exfiltration to ditch networks by lowering the water table, infiltration from

52 the ditch towards the groundwater and conveyance of water towards downstream areas

53 (Adamiade, 2004; Carluer \& Marsily, 2004; Dunn \& Mackay, 1996). A role will be

54 predominant or will not, depending on various factors, including climate, soil, direction to the

55 steepest slope and the location of the network within a catchment.

56 In Mediterranean catchments, where short but intense storms predominate, Hortonian runoff

57 is much more important than subsurface flow (Moussa et al., 2002). Hence, considering

58 surface runoff is crucial because it is closely related to flooding, water quality and erosion

59 (Fiener et al., 2011).

60 To control runoff in agricultural catchments, we can work with many anthropogenic elements,

61 such as land use and the tillage practices (Colin et al., 2011 a; Souchère et al., 2005; Takken

62 et al., 2001) or the use of grassed waterways (Fiener et al., 2003). Agricultural ditch drainage

63 networks are also one of the few structural landscape elements that control runoff and that can

64 be changed without consuming or drastically modifying the agricultural area. Therefore, the

65 relationship between agricultural ditch drainage networks and runoff is a crucial landscape

66 structure-function question that is worth investigating. In addition to this relationship, the

67 optimization of agricultural ditch drainage networks is of interest to agricultural landscape

68 managers, for example, in minimizing floods or the fate of pesticides (DGFAR, 2008).

69 Consequently, such an investigation of the relationship between agricultural ditch drainage

70 network spatial configurations and runoff will permit an assessment of the hydrological

71 benefits that we could expect through modifying these networks.

72 Because of the emphasized role of ditches in cultivated landscape hydrology, an increasing

73 number of spatially distributed models have explicitly considered ditch networks and their 
Author-produced version of the article published in Hydrological Processes, 2012, 26(22), 3393-3404.

The original publication is available at http://onlinelibrary.wiley.com

DOI:10.1002/hyp.8422

74 spatial configurations in landscapes, which have always been considered to be directed tree

75 structures (Al-Khudhairy, 1999; Branger, 2007; Carluer \& Marsily, 2004; Dunn et al., 1996;

76 Moussa et al., 2002). Consequently, these models allow for the assessment of the hydrological

77 impact of agricultural ditch drainage networks. These models can also be used to test certain

78 scenarios concerning possible evolutions of these networks. For example, Krause et al. (2007)

79 modeled the effect of removing part of an agricultural ditch drainage network on the

80 hydrology of a lowland floodplain in northeast Germany and showed that groundwater

81 recharge was altered. In the Mediterranean area, Moussa et al. (2002) found that the

82 substitution of a ditch network by a hypothetical natural drainage network that followed the

83 steepest slopes could affect runoff by decreasing peak discharge and increasing lag time.

84 However, these latter studies only considered a few scenarios, such as the suppression of the

85 agricultural parts of the drainage network.

86 Because these studies only considered a limited variability of the ditch network, they could

87 not determine, even for a given catchment, the relationship between the agricultural ditch

88 drainage network spatial configuration, i.e., network density and topology, a landscape

89 structural property, and surface runoff, a landscape functioning property. To explore the

90 relationship between the structure and the function of a landscape, the usual way to proceed in

91 environmental sciences is to couple stochastic landscape structure simulations to a landscape

92 functioning model (Colin et al., 2011 b; Gumiere, 2009; Le Ber et al., 2009; Van

93 Nieuwenhuyse et al., 2011; Viaud et al., 2005). To date, there has not been an equivalent

94 study of the impacts of agricultural ditch drainage networks on runoff.

95 In this study, the objective was to analyze the extent to which the spatial configuration and

96 especially the density of an agricultural ditch drainage network could control the surface

97 runoff of a given cultivated catchment. The investigated case study was the $6.4 \mathrm{~km}^{2}$ Bourdic

98 catchment, which is located in the Languedoc vineyards in southern France, where previous 
Author-produced version of the article published in Hydrological Processes, 2012, 26(22), 3393-3404.

The original publication is available at http://onlinelibrary.wiley.com

DOI:10.1002/hyp.8422

hydrological modeling studies could be used as source of data for the hydrological parameterization. We performed this investigation by coupling a ditch network simulator (Bailly et al., 2011) to the surface runoff functions of the MHYDAS model. We focused on

the hydrological response both at the catchment and subcatchment outlets and over hillslopes to investigate the influence of the agricultural ditch drainage network spatial configuration, i.e., density and topology, on surface runoff at various spatial scales.

\section{Material and Methods}

\subsection{Study area}

The study area was the $6.4 \mathrm{~km}^{2}$ Mediterranean Bourdic catchment (Figure 2). It is located 50 $\mathrm{km}$ west of Montpellier in southern France. The altitude varies between $45 \mathrm{~m}$ at the outlet to $128 \mathrm{~m}$ westwards. The southern part of the catchment is compounded by rather well delineated small subcatchments with gentle hillslopes whereas the northern part is relatively

flat. The land cover consists of mainly vineyards, with a small amount of cereal fields and shrubs. The actual agricultural ditch drainage network is $72 \mathrm{~km}$ long and covers all of the catchment except for the limestone uplands (cuesta) located in the center of the catchment. In

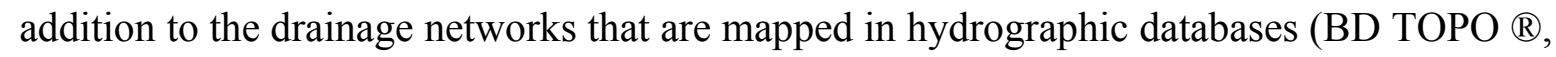
BD CARTHAGE ${ }^{\circledR}$ ), the ditches highly extend past the drainage network (72 km by 10.8 $\mathrm{km})$. The actual ditch drainage network was surveyed during the summer 2010 at an average rate of 1.5 to $3 \mathrm{~km}^{2}$ per day per person, depending on the difficulty of the terrain. Fiftycentimeter resolution aerial photographs from IGN (Insitut Géographique National) were used to locate the ditches. Agricultural ditch drainage networks are rarely represented in hydrographic databases. An exhaustive survey of the ditch sizes in a sub-catchment of $1 \mathrm{~km}^{2}$ revealed that $75 \%$ of the ditches had an upper width between 50 and $120 \mathrm{~cm}$ and a depth between 30 and $80 \mathrm{~cm}$. 
Author-produced version of the article published in Hydrological Processes, 2012, 26(22), 3393-3404.

The original publication is available at http://onlinelibrary.wiley.com

DOI:10.1002/hyp.8422

123 The Bourdic catchment contains the Roujan subcatchment (approximately $1 \mathrm{~km}^{2}$ ), where

124 numerous studies have been conducted for twenty years on soil and water resources. Because

125 it is in the Mediterranean area, high-intensity and short-duration storms are frequent and

126 Hortonian overland flow dominates subsurface flow (Moussa et al., 2002). This latter fact

127 motivated the choice of this catchment for studying the impact of agricultural ditch drainage

128 networks on runoff.

Figure 2

\subsection{Summary of the methods}

131 The general methodology of the paper relied on the coupling of a landscape simulator with a

132 distributed hydrological model (Figure 3).

Figure 3

\section{2.2.1 Stochastic simulations of ditch drainage networks}

135 The ditch network simulator has previsously been described in detail in Bailly et al. (2011),

136 and only the main principles are described below. It uses as its inputs the lattice of the field

137 units' boundaries and a Digital Terrain Model (DTM). Each segment of this lattice determines

138 a potential location for a ditch. The role of the algorithm is to select whether each potential

139 location is a ditch or not according to a stochastic drainage process and DTM uncertainties.

140 Start and end nodes of each segment of the lattice have an elevation value that is extracted

141 from the DTM. This lattice is partially directed by providing a unique direction to the lattice

142 segments that have start node and end nodes with significant differences in elevation, i.e., that

143 exceed a parameter of elevation uncertainty. For these segments, the slope is calculated as the

144 difference between the start node and the end node altitudes, divided by the length of the

145 segment. If the difference in the nodes' altitudes does not exceed the elevation uncertainty, the 146 direction of the segment is not fixed and may be different for different simulations. The 
Author-produced version of the article published in Hydrological Processes, 2012, 26(22), 3393-3404.

The original publication is available at http://onlinelibrary.wiley.com

DOI:10.1002/hyp.8422

147 segments of the lattice that correspond to the main downstream parts of the network are

148 considered invariant and are simulated as ditches for all of the ditch network simulations.

149 They define the invariant main downstream network.

150 The method of network generation consists of a stochastic drainage-like algorithm. It

151 generates directed tree network structures corresponding to connected sub-graphs of the

152 directed lattice of the agricultural field units' boundaries. The method is based on (i) directed

153 random walks throughout the directed lattice of the field units that connect randomly selected

154 segments to the invariant main downstream segments and (ii) a random branching/pruning

155 process enabling the convergence to a targeted network length. The only parameters of this

156 algorithm include the target network length, the tolerance parameter and the elevation

157 uncertainty parameter. Once the simulation process leads to a simulated network with a

158 network length that is equal to the target network length greater than or less than the tolerance

159 parameter, the simulation process stops and the simulated network is saved. With this

160 stochastic simulation process, each field unit boundary can be a ditch in a given simulation.

161 Numerous networks can thus be simulated to represent a wide variability of spatial

162 configurations, i.e., density and topology.

163 In our case study, the invariant main downstream segments came from the French national

164 databases on hydrography (BD TOPO ${ }^{\circledR}$, BD CARTHAGE $\left.{ }^{\circledR}\right)$, representing in total $10.8 \mathrm{~km}$

165 of segments (Figure 2). In fact, these segments mainly corresponded to actual channelized

166 streams and not to ditches. However, for purposes of simplification, we called agricultural

167 ditch drainage networks (or ditch networks) our simulated networks even if they contained

168 these streams. A $5 \mathrm{~m}$ resolution photogrammetric DTM ${ }^{1}$ was used for the network simulation

169 process. The elevation uncertainty parameter was fixed to $1 \mathrm{~m}$ according to the accuracy of

170 the DTM. In contrast to the study of Bailly et al. (2011), the total network length that

1 Source: Conseil Général de l’Hérault 
Author-produced version of the article published in Hydrological Processes, 2012, 26(22), 3393-3404.

The original publication is available at http://onlinelibrary.wiley.com

DOI:10.1002/hyp.8422

171 governed the simulation process was not fixed. A thousand networks were simulated, and for

172 each one, the targeted total network length was selected randomly and uniformly between a

173 minimal value that corresponded to the total length of the invariant main downstream

174 network, i.e., $10.8 \mathrm{~km}$, and a maximal value that corresponded to the total cumulative length

175 of the field units' boundaries, i.e. $220 \mathrm{~km}$.

\section{$176 \quad$ 2.2.2 Hydrological modelling}

177 The catchment hydrological behavior was simulated at the rainfall event scale using the

178 physically based rainfall runoff MHYDAS model (Modélisation Hydrologique Distribuée des

179 Agro-sytèmes - Distributed Hydrological Modeling of Agrosystems). This is a distributed

180 model that considers the catchment as a series of interconnected geographical units by which

181 infiltration/runoff partition and runoff routing are performed. Full details of the MHYDAS

182 model description are available in Moussa et al. (2000) and Moussa et al. (2002). The

183 MHYDAS model has mainly been used in the context of farming (Chahinian, 2004; Charlier,

184 2007; Gumiere et al., 2011; Hallema et al., submitted; Moussa et al., 2002; Tiemeyer et al.,

185 2007) and is available within the modeling platform Openfluid ${ }^{\circledR}$ (Fabre et al., 2010).

\section{$186 \quad$ 2.2.2.1 Landscape representation}

187 We used the landscape representation of the MHYDAS hydrological model. The

188 interconnected geographical units considered here were the field units (surface units) and the

189 ditch network (linear unit), which was located on the boundaries of field units. The Geo-

190 MHYDAS algorithm, running under GRASS GIS, was used to build a deterministic oriented

191 tree topology between these irregularly shaped surface units and linear units, which allows the

192 routing of simulated water flows across the landscape (Lagacherie et al., 2010). The Geo-

193 MHYDAS algorithm uses as its inputs a DTM and the GIS layers of the ditch network and the

194 field units. For each unit, the neighbor with the steepest slope is defined as its downstream

195 unit. 
Author-produced version of the article published in Hydrological Processes, 2012, 26(22), 3393-3404.

The original publication is available at http://onlinelibrary.wiley.com

DOI:10.1002/hyp.8422

196 In our case study, we used Geo-MHYDAS with the same $5 \mathrm{~m} \mathrm{DTM}$ as the one used for

197 network simulation. Geo-MHYDAS was thus used to define water flow paths of the surface

198 units for each simulated network and for the actual network. The topological relationship

199 between the field units and between the field units and the agricultural ditch drainage network

200 were then computed for each simulated network and resulted in different topological

201 configurations. In this process, water flow paths over the catchment (hillslopes and channels)

202 were only modified by the ditch network spatial configuration.

\section{2.2.2.2 Modeled hydrological processes}

204 Over each surface (areal) unit, MHYDAS simulated the infiltration-runoff partition as a

205 Hortonian process, while saturated runoff was neglected. The determination of the infiltration

206 rate was based on equations from Green and Ampt (1911) and Mein and Larson (1973) that

207 were adapted by Morel-Seytoux (1982) and allowed the calculation of the rainfall excess

208 under variable rain conditions. It depended on the saturated hydraulic conductivity, which was

209 a function of soil surface features that could vary in space and time. It also depended on the

210 mean initial water content at the soil surface. The other parameters were the hydraulic

211 properties of the hydrological units, such as the water content at saturation and the residual

212 water content.

213 The rainfall excess function for each unit was converted to a surface runoff hydrograph by

214 routing it to the proper outlet of the unit. The operation of converting excess rainfall into

215 surface outflow was performed by a numerical convolution involving a unit hydrograph that

216 was derived as a Hayami response function (Hayami, 1951; Moussa, 1996). This procedure

217 was a function of the mean distances between the centers of gravity of adjacent hydrological

218 units or between centers of gravity and the ditch network, the mean slope of the units and the 
Author-produced version of the article published in Hydrological Processes, 2012, 26(22), 3393-3404.

The original publication is available at http://onlinelibrary.wiley.com

DOI:10.1002/hyp.8422

219 roughness. If runoff was routed downstream via other surface units, it could be reinfiltrated to

220 these surface units.

221 Once in the network that was considered as a set of linear reaches, water was routed to the

222 catchment outlet using a diffusive wave equation. Over each reach, the parameters of the

223 diffusive wave model were calculated using the length of the reach, its slope, the coefficient

224 of roughness and the cross-sectional shape.

225 Groundwater was considered a compartment that received water that was infiltrated from

226 surface units. Water could also be exchanged between the ditch network and groundwater

227 according to the differences in water levels that were computed inside these compartments.

\subsubsection{Parameterization strategy and simulation plan}

229 Because our focus was the hydrological impact of the spatial configuration of the agricultural

230 ditch drainage network, we considered a scenario in which the other sources of hydrological

231 variability were deliberately removed. For this scenario, the corresponding parameters for the

232 surface units (saturated hydraulic conductivity, water content at saturation, residual water

233 content and roughness) and for the linear units (coefficient of roughness and cross-sectional

234 size) were made invariant in the catchment. However, the values given to these parameters

235 were selected so as to be coherent with the values that were calibrated in the previously

236 mentioned studies of the same study area. They were also selected to simulate a coherent

237 flood at the catchment outlet in comparison to the available outlet discharge data.

238 Rainfall was taken to be spatially homogeneous and was represented by a simple triangular

239 rainfall of $50 \mathrm{~mm}$ in 4 hours to symbolize high and frequent rain events. Two other rainfall

240 events, $30 \mathrm{~mm}$ in 2 hours and $60 \mathrm{~mm}$ in 4 hours, were used to test the sensitivity of the

241 simulations to the rain. This set of three rain events represented events with a return period

242 from one to two years in the area. 
Author-produced version of the article published in Hydrological Processes, 2012, 26(22), 3393-3404.

The original publication is available at http://onlinelibrary.wiley.com

DOI:10.1002/hyp.8422

243 No interaction between surface and groundwater was introduced in the modeling because we

244 focused on surface runoff and on the fast hydrological response of the catchment and

245 interaction between the ditches and groundwater was a slower process. Moreover, during

246 heavy rain events such as the one studied here, surface runoff was assumed to be the major

247 component of runoff.

248 These simplified landscape and meteorological conditions allowed us to solely test the

249 hydrological impact of the variability in the partitioning between diffuse and channelized flow

250 paths and in the associated topographic parameters. Moreover, even if we did not aim to

251 provide a validated case study, we used the model with a range of parameters and for a type of

252 rain events in which the model has been calibrated and validated several times.

\section{$253 \quad 2.3 \quad$ Evaluation of ditch network effects on hydrology}

\section{2.3.1 Classical indices}

255 To compare simulated networks with the real network and to relate network runoff variability

256 with network variability, we evaluated runoff indices (lag time, peak discharge and runoff

257 volume) at three invariant locations within the catchment (points A-C, Figure 5). At the same

258 three invariant locations, the total cumulative network length and the drained area were

259 computed.

\section{$260 \quad$ 2.3.2 Need for new indices}

261 To evaluate the variability in the runoff on the hillslopes (the overland flow), we defined an

262 adequate geographical support at which the runoff could be computed. A $500 \mathrm{~m} \times 500 \mathrm{~m}$

263 square grid was applied over the study area. Each cell of this grid was sufficiently large to

264 include a piece of the landscape (individual fields were not) and could be also held invariant

265 across simulations (subcatchments could not). 
Author-produced version of the article published in Hydrological Processes, 2012, 26(22), 3393-3404.

The original publication is available at http://onlinelibrary.wiley.com

DOI:10.1002/hyp.8422

Equation 2 Overland. flow. indicator ${ }_{\text {cell } k}=\frac{1}{n} \times \sum_{\mathrm{i}=1 \text { to } \mathrm{n}}$ Qmax $_{\text {hillslope } i}$ hillslope $i \in$ cell $k$ $k \in[1$, number of cells inside the catchment $]$

\section{Results}

\subsection{Agricultural ditch drainage network and water flow path variability}

We simulated a thousand networks, which allowed us to explore the full range of potential cumulative network lengths (Figure 5). The invariant main downstream segments were conserved in both the actual network and simulated networks. Because of the simulation process, the mean length over the set of simulated networks was higher than the actual network, which was approximately half of the cumulative field boundary length. Some very different networks were obtained, including some that were very dense (Figure 5, IV) and others that were not very dense (Figure 5, II).

The modification of water flow paths by ditch networks implied modifications in

286 subcatchment delineation and consequently the drained area (see the Roujan subcatchment 
Author-produced version of the article published in Hydrological Processes, 2012, 26(22), 3393-3404.

The original publication is available at http://onlinelibrary.wiley.com

DOI:10.1002/hyp.8422

287 defined at point B in Figure 5). To investigate this effect, we took as an example the evolution

288 of the variability in the simulated drained area along the northern main invariant segment of

289 the network (Figure 5, from point A to point C). At the start of the northern main invariant

290 segment, the coefficient of variation of the simulated drained area was higher than $100 \%$

291 (Figure 6). The coefficient of variation decreased rapidly with an increase in the mean

292 simulated drained area. However, it was still high at point B (Roujan subcatchment) (20\%).

293 The coefficient of variation rapidly decreased to $5 \%$ for a mean simulated drained area of 1.7

$294 \mathrm{~km}^{2}$. This high variability of the drained area emphasized the role of the ditch drainage

295 network in modifying water flow paths. After the confluence with the southern main invariant

296 segment, the coefficient of variation was low (decreasing to $2 \%$ ). The decreasing variability

297 of the drained area along the main invariant segment could be explained by (i) the simulated

298 drained area that became increasingly constrained by the catchment morphology and the

299 invariant main segments near the outlet and (ii) the whole catchment boundary that was fixed

300 for all of the simulations.

\section{$302 \quad 3.2$ Discharge variability and scaling}

303 We computed the hydrographs at three points along the northern main downstream segment

304 of the network (Figure 7), including the starting point of the invariant main downstream

305 network (Figure 5, point A), at $1000 \mathrm{~m}$ downstream (Figure 5, point B, corresponding to the

306 Roujan subcatchment) and at the outlet, $5000 \mathrm{~m}$ downstream (Figure 5, point $\mathrm{C}$,

307 corresponding to the Bourdic catchment). The hydrographs exhibited a high variability in

308 amplitude, but the shapes of the actual hydrographs were preserved across the simulated

309 networks. For point A, the high variability that was observed was mainly related to the very

310 high variability in the area that was drained at this point (Figure 6). In some cases, this point 
Author-produced version of the article published in Hydrological Processes, 2012, 26(22), 3393-3404.

The original publication is available at http://onlinelibrary.wiley.com

DOI:10.1002/hyp.8422

311 corresponded to a source, as no ditch was present upstream and it did not drain any field unit.

312 On the contrary, an upstream ditch network that drained several field units, could be branched

313 upstream of this point for other simulations. For the two other points, the Roujan

314 subcatchment and the Bourdic catchment, the variability in hydrographs remained high

315 despite the smaller variability in the drained area. We hypothesized this property to be related 316 to other network characteristics, especially network density.

318 We calculated lag times, peak discharges and total volumes from the 1,001 hydrographs. We

319 focused on the sensitivity of these runoff indices to the variation in network lengths at two

320 specific locations (Figure 8): at the outlet of a small upstream watershed, the Roujan

321 subcatchment (the second hydrograph on Figure 6, point B on Figure 5) and at the outlet of

322 the whole Bourdic catchment (the third hydrograph on Figure 6, point $\mathrm{C}$ on Figure 5). At the

323 Bourdic catchment outlet, the range in peak discharge was -50 to $+24 \%$ compared with the

324 value that was simulated for the actual network. The range in total volume was -55 to $+14 \%$.

325 Furthermore, the peak discharge and total volume quickly increased with the network length

326 and then reached a plateau. This plateau corresponded to a situation in which all of the fields

327 units were connected to a ditch. Indeed, the denser the network, the greater the connectivity

328 between the field units and the ditch network, which limited the re-infiltration to the fields.

329 The lag time exhibited a more complicated trend and less relative variability $(-15$ to $+12 \%$ in

330 comparison with the value simulated for the actual network). First, there was a quick increase

331 and then a slow decrease as the network length increased. We hypothesized that for short

332 networks, only the runoff of the closest area to the outlet contributed to the flood and that the

333 runoff of the more distant areas was reinfiltrated before reaching the network. For dense

334 networks, distant areas contributed to the flood and thus the lag time was higher because of

335 longer average flow paths. Then, when all areas contributed runoff and the network grew 
Author-produced version of the article published in Hydrological Processes, 2012, 26(22), 3393-3404.

The original publication is available at http://onlinelibrary.wiley.com

DOI:10.1002/hyp.8422

336 again, flow paths were increasingly channelized in the networks, which decreased the lag time

337 because the mean celerity was higher in the network than in the field (Moussa et al., 2002).

338 Even if the catchment area was constant at the outlet, there was a variability in runoff for a

339 given network length. This variability may have been caused by variability in the topographic

340 parameters or the topology of the ditch networks.

341 The variability was more significant for the Roujan subcatchment scale. The lag time, peak

342 discharge and total volume ranged from -18 to $+90 \%,-96$ to $+19 \%$ and -71 to $+29 \%$,

343 respectively, in comparison with the simulated value for the actual network. An obvious

344 reason was the fact that the drained area varied for the Roujan subcatchment outlet, but not at

345 the Bourdic catchment outlet (Figure 6). However, there was also a clear trend for the peak

346 discharge and total volume at the Roujan outlet: these variables increased as the network

347 length increased. A trend was more difficult to identify for the lag time, but we observed a

348 decrease with increasing network length.

Figure 8

350 Finally, we also investigated whether the relationship between the runoff metrics and the

351 length of the ditch drainage network was dependent on the rain event. With two other

352 triangular rain events, i.e., $30 \mathrm{~mm}$ in 2 hours and $60 \mathrm{~mm}$ in 4 hours, the type of relationship

353 was not changed. An example of the peak discharge as a function of the ditch network length

354 is shown in Figure 9.

Figure 9

\section{$356 \quad 3.3$ Hillslope overland flow variability}

357 Using the squared grid and the method described above (Figure 4), we observed how the overland flow indicator varied inside every cell grid on the catchment. Figure 10 shows an example of a cell that was located in the western part of the catchment, mainly in a zone with 
Author-produced version of the article published in Hydrological Processes, 2012, 26(22), 3393-3404.

The original publication is available at http://onlinelibrary.wiley.com

DOI:10.1002/hyp.8422

360 slopes greater than $10 \%$. The overland flow indicator decreased exponentially as the

361 cumulative ditch network length increased and trended toward an asymptote across the

362 highest drainage densities. Approximately $25 \%$ of the maximum drainage density

363 (approximately $2150 \mathrm{~m}$ in this cell) corresponded to a third of the maximum overland flow

$364\left(6.91 . \mathrm{s}^{-1}\right.$ against $\left.211 . \mathrm{s}^{-1}\right)$. For a given network length within a cell, a small amount of

365 variability remained, which corresponded to the efficiency of the network to intercept

366 overland flow. For example, if $2000 \mathrm{~m}$ of ditches were grouped into a small part of a cell or

367 were parallel to the highest slope, they intercepted less overland flow than if they were well

368 distributed throughout the cell and were perpendicular to the highest slope. We also noticed

369 the position of the actual network, in that simulated networks with similar lengths produced

370 more overland flow in the cell than the actual network.

371 As for the example cell in Figure 10, a trend line could be fitted for each cell. To represent the

372 exponential decrease of the overland flow indicator as a function of network length, a model

373 in the form of overland.flow $=\mathrm{a}+\mathrm{b} \times \exp (-\mathrm{c} \times$ network.length $)$ was fitted. We used a non-linear

374 least-squares algorithm for the estimation of the $\mathrm{a}, \mathrm{b}$ and $\mathrm{c}$ parameters. The median coefficient

375 of determination $\left(\mathrm{R}^{2}\right)$ between the fitted and actual values of the overland flow indicator was

376 equal to 0.96 , which indicated a very good fit and an overland flow indicator that was closely

377 dependent on the drainage density. The exponential decrease revealed that few ditches were

378 efficient in greatly limiting overland flow and that more and more ditches were needed to

379 further reduce the overland flow. 


\section{Discussion}

\subsection{Importance of the agricultural ditch drainage network on the} hydrology of a small, cultivated catchment

Agricultural ditch drainage networks are known to influence the runoff of small, cultivated catchments (Carluer \& Marsily, 2004; Moussa et al., 2002). However, the nature of this statement is dependent on the studied area and its actual network and is generally made through a comparison with a hypothetical natural network that is extracted from a DTM. In this study, the importance of ditch networks was confirmed in a more general context, even though it was still dependent on the catchment morphology and field geometry. Among the set of simulated networks, the variability in the area drained was very high, which reinforced the evidence that linear features alter overland flow-paths (Duke et al., 2006; Gascuel-Odoux et al., 2011). Therefore, our study revealed how agricultural ditch drainage networks can modify delivery pathways, which is a major component of the hydrological connectivity of a catchment (Bracken \& Croke, 2007).

The runoff variability was very high, both on the scale of the whole Bourdic catchment and the Roujan subcatchment. The peak discharge and total volume clearly increased with network density, but they also depended on other induced changes (e.g. topology and slope of the networks), which should be better quantified in the future. These results agreed with the study of Moussa et al. (2002), which concluded that agricultural ditch drainage networks accelerated runoff. However, we showed that this statement clearly depended on the drainage density. Concerning runoff on the hillslopes, we showed that the ditches that were present on hillslopes intercepted the diffuse water flow paths and rapidly decreased the overland flow. However, above a certain network density, adding new ditches became less and less efficient

4 for decreasing overland flow. 
Author-produced version of the article published in Hydrological Processes, 2012, 26(22), 3393-3404.

The original publication is available at http://onlinelibrary.wiley.com

DOI:10.1002/hyp.8422

405 Our study also confirmed the predominant role of ditches in intercepting overland flow on the

406 hillslopes in Mediterranean areas (Martínez-Casasnovas et al., 2002) and enabled the better

407 quantification of the relationship between the density of the ditch network and the overland

408 flow. This interception of overland flow thus explained the statistical effects of ditches in

409 reducing erosion that was observed in the study by Paroissien et al. (2010).

410 Finally, these results showed the effects of removing or adding ditches to a drainage network

411 when no other field borders were considered when removing ditches. Conversely, in

412 Verstraeten et al. (2002), replacing the ditches with grassed waterways was considered and

413 was shown to reduce sediment delivery. Such an investigation was not considered here, and

414 no obstacle to the runoff were considered between two given field units after removing a

415 ditch.

\section{$416 \quad 4.2$ Catchment extent effect}

417 All of these findings were dependent on the extent of catchments. At any point of the

418 catchment, a high variability in the network induced a high variability in runoff, but the

419 variability in runoff was higher at the Roujan subcatchment scale than at the whole Bourdic

420 catchment scale at any given network density. This fact was explained by the high variability

421 in the area that was drained in the upstream part of the network, whereas the low variability in

422 the area that was drained, the morphology of the catchment and the invariant main

423 downstream network constrained the routing of the runoff and all served to limit the

424 downstream variability (from approximately $2 \mathrm{~km}^{2}$ ).

425 Concerning the hillslope overland flow, the effect of scale was not investigated in this study.

426 However, the extent effect was considered to become significant with a decreasing cell size

427 that would increase the overland flow indicator variability. A $500 \mathrm{~m} \times 500 \mathrm{~m}$ square grid

428 seemed to be appropriate because, in contrast to individual field units, it was sufficiently large 
Author-produced version of the article published in Hydrological Processes, 2012, 26(22), 3393-3404.

The original publication is available at http://onlinelibrary.wiley.com

DOI:10.1002/hyp.8422

429 to include a piece of the landscape (which individual field units were not) and was sufficiently

430 fine to enable the spatialization of overland flow in a small cultivated catchment with

431 sufficient detail.

\section{$432 \quad 4.3$ Hydrological efficiency}

433 The actual ditch network seemed to be quite efficient in comparison with the simulated

434 networks for draining floods (Figure 8) and limiting overland flow on the hillslopes (Figure

435 10). For instance, when looking at the peak discharge and the total volume of all of the points

436 of the main invariant segments of the networks, the drainage that was provided by the actual

437 network was almost always greater than the fitted value for the simulations, and the lag time

438 was shorter (Figure 11). The actual network drained more water and accomplished that more

439 rapidly. For the overland flow on the hillslopes, the overland flow indicator was almost

440 always lower than that of the simulated networks; therefore, for a given length, the actual

441 network intercepted more overland flow than the simulated networks. However, an optimum

442 network should be not only more efficient than a network of similar length, but also a

443 compromise between the network length and the hydrological efficiency because the

444 maintenance of the ditch network requires a tremendous amount of work from farmers. To

445 define such an optimum network, we must take into account the local conditions that

446 influence the overland flow, such as land cover and soil properties. Therefore, we could not

447 accomplish this task here. Finally, we question whether the actual agricultural ditch drainage

448 network is optimal in all agricultural catchments or if this was the case in the Bourdic

449 catchment only.

451 Current agricultural ditch drainage networks are the results of a sum of individual ditch

452 digging efforts of hundreds of farmers over the last two thousand years (Berger et al., 2000), 
Author-produced version of the article published in Hydrological Processes, 2012, 26(22), 3393-3404.

The original publication is available at http://onlinelibrary.wiley.com

DOI:10.1002/hyp.8422

453 and they continue to evolve. Therefore, we may wonder how this optimum can emerge from a

454 sum of individual decisions. A survey of farmers would be useful to understand this finding

455 and would perhaps highlight some guidelines for the creation of ditch drainage networks and

456 cooperation between farmers, which could be further implemented in the simulation

457 algorithm.

\section{4.4 Limitations and uncertainties in results}

459 This modeling study revealed the effects of modifications in the spatial configurations of

460 ditch networks in an agricultural catchment, which can not be tested in the real world.

461 However, even if the model was previously used and validated in this area, we used this

462 model in virtual conditions and outside its tested bounds (concerning drainage density).

463 Therefore, like in all studies testing scenarios, we must carefully interpret the results

464 (Silberstein, 2006).

465 The results of this study should thus not be taken as universal, but the trends deserve

466 consideration. In addition to these first limitations, the simplified hydrological case studied

467 here does not allow for confidence in absolute values. Thus, this type of study should be

468 extended to more complicated cases with various actual rain events and a realistically

469 distributed land cover. Indeed, in our case study, each field unit generated the same amount of

470 runoff, which would obviously be inaccurate in a real landscape. The consideration of

471 patterns of runoff generation would probably modify the effect of the ditch networks. This

472 effect would most likely be reinforced in areas with a high production of runoff and lessened

473 in other areas. Ditch networks could thus modify the delimitation of active areas (Ambroise,

474 2004), for example, by avoiding the runoff that is produced in a low-permeability area to be

475 reinfiltrated to a permeable area that is located downslope. 
Author-produced version of the article published in Hydrological Processes, 2012, 26(22), 3393-3404.

The original publication is available at http://onlinelibrary.wiley.com

DOI:10.1002/hyp.8422

476 Another limitation concerns the parameterization of the ditch. First, neither infiltration into

477 the ditch network nor ex-filtration were considered in this study, whereas groundwater

478 recharge by channel infiltration may be important in Mediterranean and semi-arid areas

479 (Dages et al. 2009; Ponce et al., 1999). If such an interaction was modeled, the network

480 hydrology would probably have been much more complex, with patterns of infiltration and

481 ex-filtration along the network, and the relation between network density and runoff may have

482 been modified. Accordingly, we decided to focus on surface runoff in this study. Moreover,

483 the calibration of the exchange function between a ditch network and groundwater is very

484 delicate, especially with a variable network. Therefore, the interactions between surface and

485 ground water in the ditches should be considered in future works, especially when studying

486 rain events with lower intensities. The second limitation concerning the parameterization of

487 the ditches involved their cross-sectional size and roughness which were considered invariant

488 in our study. These parameters greatly affect surface runoff (Nédélec et al., 2004) and are

489 known to be highly spatially variable, both in natural streams (O'Hare et al., 2010) and in

490 small agricultural ditches (Bouldin et al., 2004; Crabit et al., 2011). These limitations should

491 therefore be addressed in future works, with the use of spatial models of these ditch

492 parameters, as it exists for ditch cross-sectional sizes (Bailly et al., 2006).

493 To summarize, the results concerning the hydrological response of the network should thus be

494 carefully interpreted. The results on overland flow in the fields seemed more robust because

495 they were not affected by the simplification of the parameterization of the ditches.

496 Finally, the high variability that was observed here was predominantly a result of the high

497 variability in the drainage density. However, some of this variability was improbable,

498 especially the variability that resulted from including the very high drainage densities.

499 However, their inclusion provided the advantage of defining what was possible. Compared

500 with the large survey that was realized in the Hérault French département (Levavasseur et al., 
Author-produced version of the article published in Hydrological Processes, 2012, 26(22), 3393-3404.

The original publication is available at http://onlinelibrary.wiley.com

DOI:10.1002/hyp.8422

501 submitted), the drainage density observed in the Bourdic catchment was one of the highest

502 densities that has been observed. Therefore, the most interesting part of this study concerned

503 low drainage densities for which hydrological sensitivity appeared to be the highest.

504 The coupling of a ditch network simulator with a hydrological model provided several

505 interesting results and offered new prospects. Here, we used this method to investigate the

506 impact of the spatial configuration of agricultural ditch drainage networks on the hydrology of

507 a small catchment. We could imagine that this type of method could also be used to test

508 certain scenarios of landscape arrangements or to optimize an existing network, as it has been

509 done with land use patterns (Newbold, 2005; Seppelt \& Voinov, 2002). For example, the

510 minimization of the peak discharge at the outlet combined with the minimization of overland

511 flow on hillslopes could be accomplished by branching or pruning the existing network. The

512 optimization of the network could also concern reductions in erosion or pesticides impacts by

513 coupling with appropriate models (Gumiere et al., 2011).

\section{Conclusions}

515 A ditch network simulator coupled with a distributed hydrological model allowed for a study

516 of how runoff is related to the densities of an agricultural ditch drainage network in cultivated

517 landscapes. New hydrological and network parameters were defined to deal with the

518 variations in hillslope and subcatchment delineations that were induced by variations in the

519 ditch drainage networks.

520 The importance of spatial configurations of agricultural ditch drainage networks in the

521 alteration of water flow paths and in the control of runoff was highlighted, both in

522 channelized flow-paths and on hillslopes. From our case study, we observed that variability of

523 the spatial configuration and especially an increase of the ditch network density strongly

524 influenced the subcatchment delineation and area, increased the drained volume and the peak 
Author-produced version of the article published in Hydrological Processes, 2012, 26(22), 3393-3404.

The original publication is available at http://onlinelibrary.wiley.com

DOI:10.1002/hyp.8422

525 discharge and decreased overland flow on hillslopes. However, these hydrological behaviors

526 were only sensitive to network density for drainage networks with densities that did not

527 exceed a certain threshold. This study also highlighted the efficiency of the actual network in

528 comparison with the networks that were simulated by the ditch network simulator, which

529 suggest an anthropogenic optimization process that should be further explored.

\section{Acknowledgement}

531 This work was partly supported by the French Languedoc-Roussillon région, via a Ph.D.

532 thesis grant. The authors also thank Adeline Bellet, an M.Sc. student, who helped with field

533 surveys.

\section{References}

535 Adamiade V. 2004. Influence d’un fossé sur les écoulements rapides au sein d’un versant.

536 PhD Dissertation, Université Pierre et Marie Curie, Paris, France.

537 Al-Khudhairy DHA, Thompson JR, Gavin H, Hamm NAS. 1999. Hydrological modelling of

538 a drained grazing marsh under agricultural land use and the simulation of restoration

539 management scenarios. Hydrological Sciences Journal 44: 943-971.

540 Ambroise B. 2004. Variable 'active' versus 'contributing' areas or periods: a necessary

541 distinction. Hydrological Processes 18: 1149-1155.

542 Bailly JS, Monestiez P, Lagacherie P. 2006. Modelling Spatial Variability Along Drainage

543 Networks with Geostatistics. Mathematical Geology 38: 515-539.

544 Bailly JS, Levavasseur F, Lagacherie P. 2011. A spatial stochastic algorithm to reconstruct

545 artificial drainage networks from incomplete network delineations. International Journal of

546 Earth Observation And Geology 13: 853-862. 
Author-produced version of the article published in Hydrological Processes, 2012, 26(22), 3393-3404.

The original publication is available at http://onlinelibrary.wiley.com

DOI:10.1002/hyp.8422

547 Berger JF. 2000. Les fossés bordiers historiques et l'histoire agraire rhodanienne. Etudes

548 Rurales.

549 Bevan A, Conolly J. 2011. Terraced fields and Mediterranean landscape structure: An

550 analytical case study from Antikythera, Greece. Ecological Modelling 222: 1303-1314.

551 Bouldin JL, Farris JL, Moore MT, Cooper CM. 2004. Vegetative and structural characteristics

552 of agricultural drainages in the Mississippi Delta landscapes. Environmental Pollution 132:

553 403-411.

554 Bracken LJ, Croke J. The concept of hydrological connectivity and its contribution to

555 understanding runoff-dominated geomorphic systems. Hydrological Processes 21: 1749-1763

556 Branger F. 2007. Utilisation d'une plate-forme de modélisation environnementale pour

557 représenter le rôle d'aménagements hydro-agricoles sur les flux d'eau et de pesticides.

558 Application au bassin versant de la Fontaine du Theil (Ille et Vilaine). PhD Dissertation,

559 Université de Grenoble, France.

560 Carluer N, Marsily GD. 2004. Assessment and modelling of the influence of man-made

561 networks on the hydrology of a small watershed: implications for fast flow components, water

562 quality and landscape management. Journal of Hydrology 285: 76-95.

563 Chahinian N. 2004. Paramétrisation multi-critère et multi-échelle d un modèle hydrologique

564 spatialisé de crue en milieu agricole. PhD Dissertation, Université Montpellier II, France.

565 Charlier, JB. 2007. Fonctionnement et modélisation hydrologique d'un petit bassin versant

566 cultivé en milieu volcanique tropical. PhD Dissertation, Université Montpellier II, France.

567 Colin F, Moussa R, Louchart X. 2011 a. Impact of the spatial arrangement of land

568 management practices on surface runoff for small catchments. Hydrological Processes, in

569 press. 
Author-produced version of the article published in Hydrological Processes, 2012, 26(22), 3393-3404.

The original publication is available at http://onlinelibrary.wiley.com

DOI:10.1002/hyp.8422

570 Colin F, Guillaume S, Tisseyre B. 2011 b. Small catchment agricultural management using

571 decision variables defined at catchment scale and fuzzy rule based system: A Mediterranean

572 vineyard case study. Water Resources Management 25: 2649-2668.

573 Crabit A, Colin F, Moussa R. 2011. A soft hydrological monitoring approach for comparing

574 runoff on a network of small poorly gauged catchments. Hydrological Processes 25: 2785-

5752800.

576 Dagès C, Voltz M, Bsaibes A, Prévot L, Huttel O, Louchart X, Garnier F, Négro S. 2009.

577 Estimating the role of a ditch network in groundwater recharge in a Mediterranean catchment

578 using a water balance approach. Journal of Hydrology 375: 498-512.

579 DGFAR - Direction générale de la forêt et des affaires rurales, Circulaire 2008 «mesures

580 agroenvironnementales », Available at: http://agriculture.gouv.fr/circulaire-dgfar-sdea-c20085815026

582 Duke GD, Kienzle SW, Johnson DL, Byrne JM. 2006. Incorporating ancillary data to refine

583 anthropogenically modified overland flow paths. Hydrological Processes 20: 1827-1843.

584 Dunn SM, Mackay R. 1996. Modelling the hydrological impacts of open ditch drainage.

585 Journal of Hydrology 179: 37-66.

586 Fabre JC, Louchart X, Colin F, Dagès C, Moussa R, Rabotin M, Raclot D, Lagacherie P,

587 Voltz M. 2010. OpenFluid: a software environment for modelling fluxes in landscapes. In

588 LandMod 2010: International Conference on Integrative Landscape Modelling. Montpellier,

589 France.

590 Fiener P, Auerswald K. 2003. Effectiveness of grassed waterways in reducing runoff and

591 sediment delivery from agricultural watersheds. Journal of Environmental Quality 32: 927-

592936. 
Author-produced version of the article published in Hydrological Processes, 2012, 26(22), 3393-3404.

The original publication is available at http://onlinelibrary.wiley.com

DOI:10.1002/hyp.8422

593 Fiener P, Auerswald K, Van Oost K. 2011. Spatio-temporal patterns in land use and

594 management affecting surface runoff response of agricultural catchments--A review. Earth-

595 Science Reviews 106: 92-104.

596 Forman RTT, Baudry J. 1984. Hedgerows and hedgerow networks in landscape ecology.

597 Environmental Management 8: 495-510.

598 Gascuel-Odoux C, Aurousseau P, Doray T, Squividant H, Macary F, Uny D, Grimaldi C.

599 2011. Incorporating landscape features to obtain an object-oriented landscape drainage

600 network representing the connectivity of surface flow pathways over rural catchments.

601 Hydrological Processes 25: 3625-3636.

602 Green W, Ampt G. 1911. Studies on soil physics part I: the flow of air and water through

603 soils. Journal of Agricultural Science 4: 1-24.

604 Gumiere SJ. 2009. Contribution à la modélisation déterministe spatialisée de l'érosion

605 hydrique des sols à l'échelle des petits bassins versants cultivés. PhD Dissertation ,

606 Montpellier SupAgro, France.

607 Gumiere SJ, Raclot D, Cheviron B, Davy G, Louchart X, Fabre JC, Moussa R, Le Bissonnais

608 Y. 2011. MHYDAS-Erosion: a distributed single-storm water erosion model for agricultural

609 catchments. Hydrological Processes 25: 1717-1728.

610 Hallema D, Moussa R, Andrieux P, Voltz M. Parameterisation and multi-criteria calibration

611 of a fully distributed storm flow model applied to a Mediterranean agricultural catchment.

612 Submitted in Hydrological Processes.

613 Hayami, S. 1951. On the propagation of flood waves. Disaster Prev. Res. Inst. Bull. 1: 1-16.

614 Herzon I, Helenius J. 2008. Agricultural drainage ditches, their biological importance and

615 functioning. Biological Conservation 141: 1171-1183. 
Author-produced version of the article published in Hydrological Processes, 2012, 26(22), 3393-3404.

The original publication is available at http://onlinelibrary.wiley.com

DOI:10.1002/hyp.8422

616 Krause S, Jacobs J, Bronstert A. 2007. Modelling the impacts of land-use and drainage

617 density on the water balance of a lowland-floodplain landscape in northeast Germany.

618 Ecological Modelling, 200: 475-492.

619 Lagacherie P, Rabotin M, Colin F, Moussa R, Voltz M. 2010. Geo-MHYDAS: A landscape

620 discretization tool for distributed hydrological modeling of cultivated areas. Computers \&

621 Geosciences 36: 1021-1032.

622 Le Ber F, Lavigne C, Adamczyk K, Angevin F, Colbach N, Mari JF, Monod H. 2009. Neutral

623 modelling of agricultural landscapes by tessellation methods - Application for gene flow

624 simulation. Ecological Modelling, 220: 3536-3545.

625 Levavasseur F, Lagacherie P, Bailly JS, Biarnès A, Colin F. High spatial variability and

626 prediction of the density of agricultural ditches in a Mediterranean vineyards landscape.

627 Submitted in Applied Geography.

628 Martínez-Casasnovas JA, Ramos MC, Ribes-Dasi M. 2002. Soil erosion caused by extreme

629 rainfall events: mapping and quantification in agricultural plots from very detailed digital

630 elevation models. Geoderma 105, 125-140.

631 Mein RG, Larson CL. 1973. Modelling infiltration during a steady rain. Water Resources

632 Research 9: 384-394.

633 Morel-Seytoux HJ. 1978. Derivation of equations for variable rainfall infiltration. Water

634 Resources Research 14: 561-568.

635 Moussa, R. 1996. Analytical Hayami Solution for the Diffusive Wave Flood Routing Problem

636 with Lateral Inflow. Hydrological Processes 10: 1209-1227.

637 Moussa R, Voltz M, Andrieux P, Lagacherie P. 2000. Hydrological modelling of a farmed

638 mediterranean catchment. In Mediterranean Storms, Claps P, Siccardi F (eds). European

639 Geophysical Society Plinius Conference'99 : 377-386. 
Author-produced version of the article published in Hydrological Processes, 2012, 26(22), 3393-3404.

The original publication is available at http://onlinelibrary.wiley.com

DOI:10.1002/hyp.8422

640 Moussa R, Voltz M, Andrieux P. 2002. Effects of the spatial organization of agricultural

641 management on the hydrological behaviour of a farmed catchment during flood events.

642 Hydrological Processes 16: 393-412.

643 Nédélec Y, Kao C, Chaumont C. 2004. Réduction des transferts de crues dans les bassins

644 versants agricoles fortement drainés : état des connaissances et des recherches. Ingénieries -

645 EAT 37: 3-21.

646 Newbold SC. 2005. A combined hydrologic simulation and landscape design model to

647 prioritize sites for wetlands restoration. Environmental Modeling \& Assessment 10: 251-263.

648 O’Hare MT, McGahey C, Bissett N, Cailes C, Henville P, Scarlett P. Variability in roughness

649 measurements for vegetated rivers near base flow, in England and Scotland. Journal of

650 Hydrology 385: 361-370.

651 Paroissien JB, Lagacherie P, Le Bissonnais Y. 2010. A regional-scale study of multi-

652 decennial erosion of vineyard fields using vine-stock unearthing-burying measurements.

653 CATENA, 82: 159-168.

654 Pita R, Mira A, Beja P. 2006. Conserving the Cabrera vole, Microtus cabrerae, in intensively

655 used Mediterranean landscapes. Agriculture, Ecosystems and Environment 115: 1-5.

656 Ponce VM, Pandey RP, Kumar S. 1999. Groundwater recharge by channel infiltration in El

657 Barbon basin, Baja California, Mexico. Journal of Hydrology 214: 1-7.

658 Seppelt R, Voinov A. 2002. Optimization methodology for land use patterns using spatially

659 explicit landscape models. Ecological Modelling 151: 125-142.

660 Silberstein RP. Hydrological models are so good, do we still need data? Environmental

661 Modelling \& Software 21: 1340-1352.

662 Souchère V, Cerdan O, Dubreuil N, Le Bissonnais Y, King C. 2005. Modelling the impact of

663 agri-environmental scenarios on runoff in a cultivated catchment (Normandy, France).

664 CATENA 61: 229-240. 
Author-produced version of the article published in Hydrological Processes, 2012, 26(22), 3393-3404.

The original publication is available at http://onlinelibrary.wiley.com

DOI:10.1002/hyp.8422

665 Takken I, Govers G, Steegen A, Nachtergaele J, Guérif J. 2001. The prediction of runoff flow

666 directions on tilled fields. Journal of Hydrology 248: 1-13.

667 Tiemeyer B, Moussa R, Lennartz B, Voltz M. 2007. MHYDAS-DRAIN: A spatially

668 distributed model for small, artificially drained lowland catchments. Ecological Modelling

669 209: 2-20.

670 Van Nieuwenhuyse BHJ, Michael A, Wyseure G, Govers G. 2011. Pattern-process

671 relationships in surface hydrology: hydrological connectivity expressed in landscape metrics.

672 Hydrological Processes, in press.

673 Verstraeten G, Oost K, Rompaey A, Poesen J, Govers G. Evaluating an integrated approach

674 to catchment management to reduce soil loss and sediment pollution through modelling. Soil

675 Use and Management 18: 386-394.

676 Viaud V, Durand P, Merot P, Sauboua E, Saadi Z. 2005. Modeling the impact of the spatial

677 structure of a hedge network on the hydrology of a small catchment in a temperate climate.

678 Agricultural Water Management 74: 135-163.

679 Watson AM, Ormerod S. 2004. The distribution of three uncommon freshwater gastropods in

680 the drainage ditches of British grazing marshes, Biological Conservation 118: 455-466. 
Author-produced version of the article published in Hydrological Processes, 2012, 26(22), 3393-3404.

The original publication is available at http://onlinelibrary.wiley.com

DOI:10.1002/hyp.8422

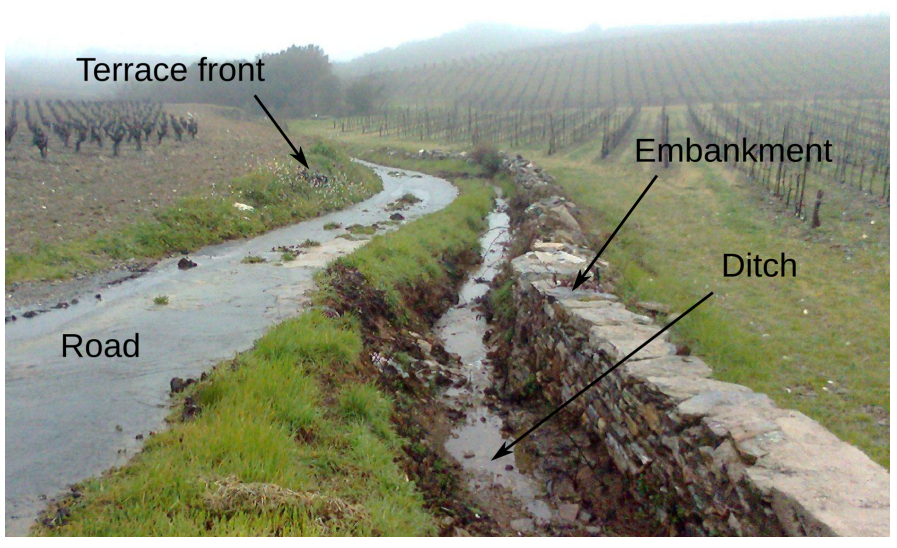

Figure 1: Linear features in cultivated landscapes. Ditches and roads channel water, whereas embankments act as barriers to water flow. 
Author-produced version of the article published in Hydrological Processes, 2012, 26(22), 3393-3404.

The original publication is available at http://onlinelibrary.wiley.com

DOI:10.1002/hyp.8422

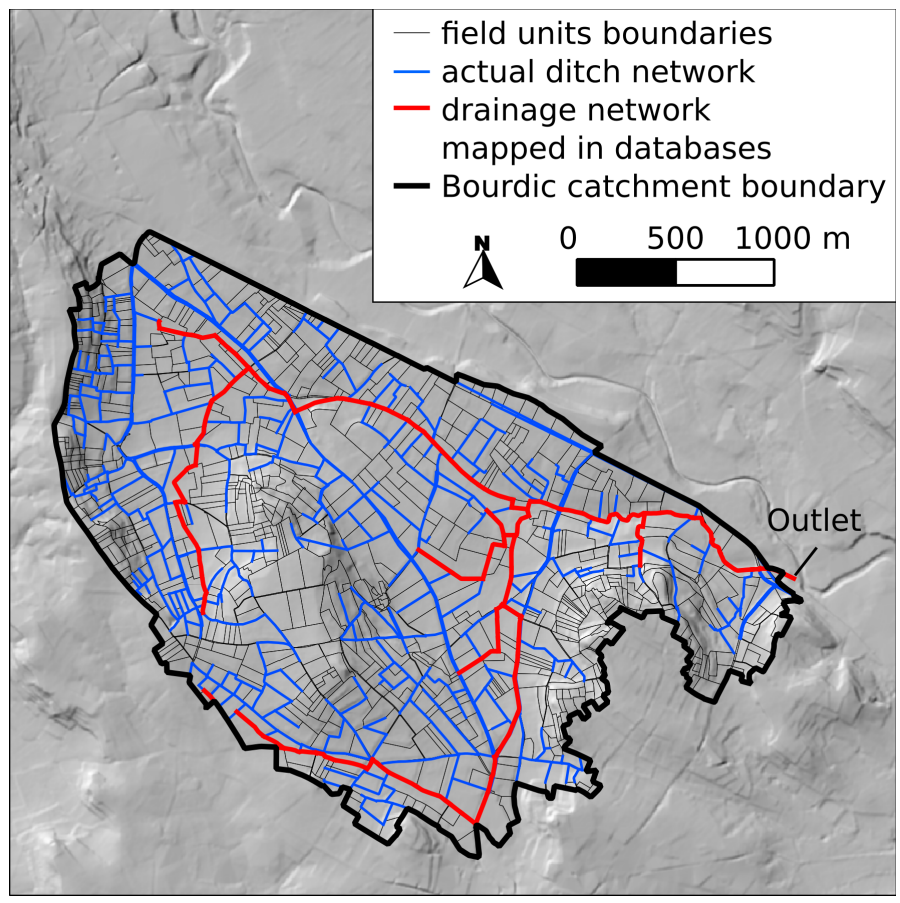

Figure 2: Study area. Drainage network of the Bourdic catchment is represented in a hillshade view, with an azimuth to the light equal to $315^{\circ}$. The inclusion of the agricultural ditch drainage network greatly expanded the drainage network that was mapped in hydrographic databases. 
Author-produced version of the article published in Hydrological Processes, 2012, 26(22), 3393-3404.

The original publication is available at http://onlinelibrary.wiley.com

DOI:10.1002/hyp.8422

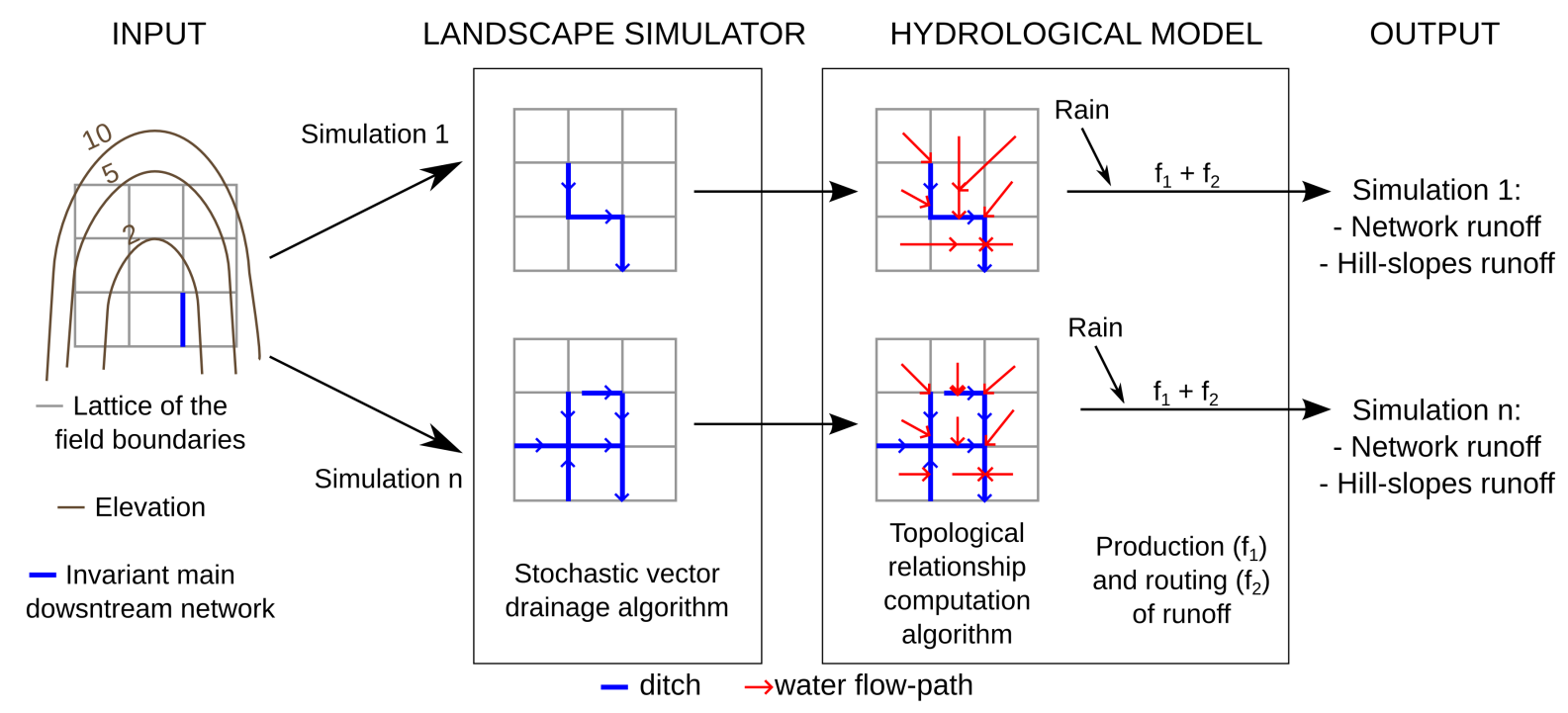

Figure 3: Conceptual diagram of the methodology: coupling of a stochastic vector drainage algorithm with distributed hydrological modelling to study the impact of the network structure of agricultural ditch drainage on surface runoff. 
Author-produced version of the article published in Hydrological Processes, 2012, 26(22), 3393-3404.

The original publication is available at http://onlinelibrary.wiley.com

DOI:10.1002/hyp.8422

Squared grid applied on the catchment

Detail of the fields in a cell
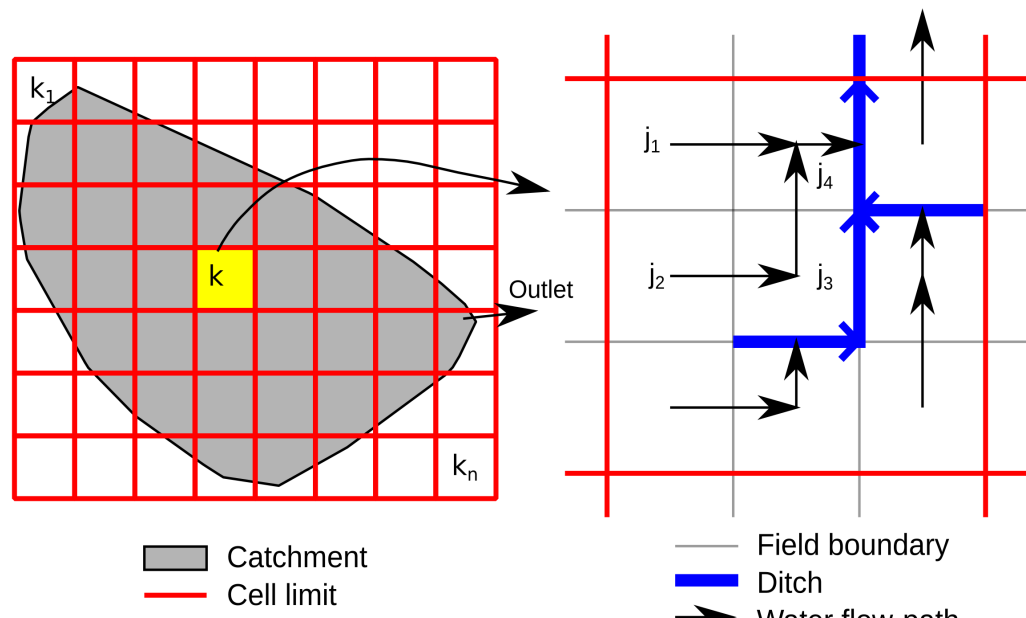

Delineation of the hillslopes in a cell
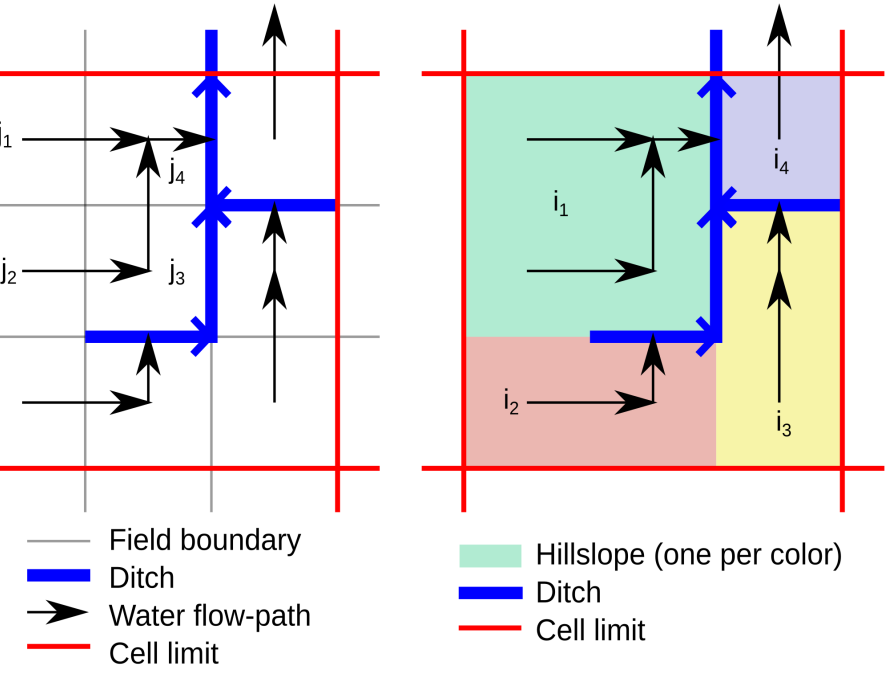

Hillslope (one per color)

Ditch

Cell limit

Figure 4: Space discretization used to compute an overland flow indicator value. Hillslopes were delineated in each cell of the grid applied on the catchment. Then, the overland flow indicator of a cell was calculated as the mean of the maximum field unit (j) overland flow of all the hillslopes (i) inside the cell (Equations 1 and 2). 

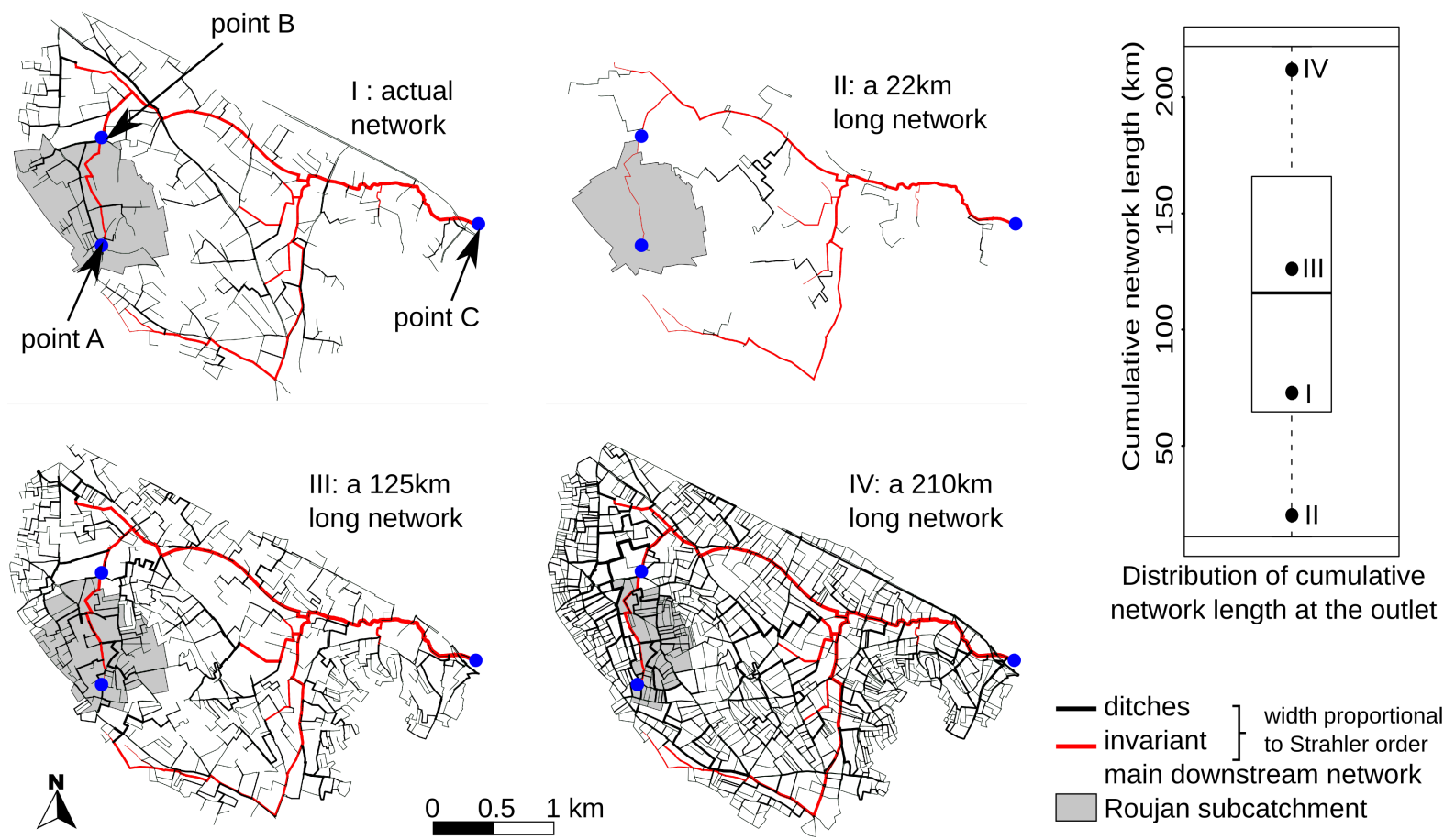

Figure 5: Variability of the spatial configuration and length of the drainage networks. Both small and very dense networks were simulated. We also observed variability in the delineation of subcatchments. 


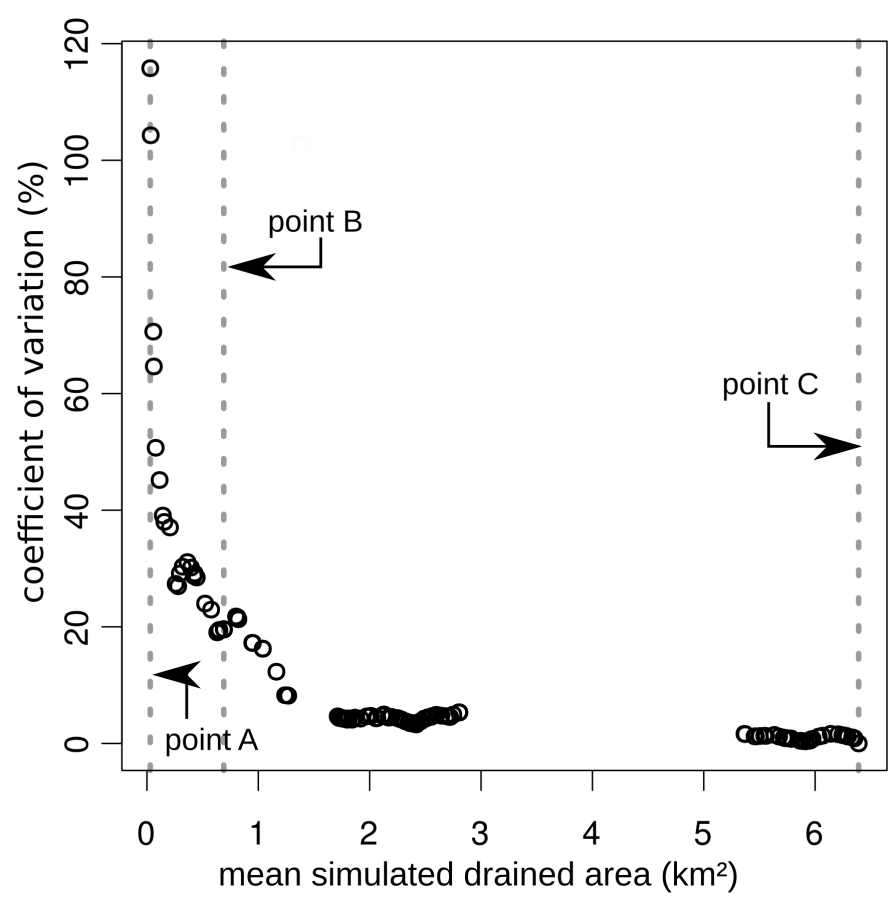

Figure 6: Coefficient of variation $(\mathrm{CV})$ for the drainage area along the northern main invariant segment of the network (Fig. 5). The CV was calculated based on 1001 realizations of the ditch network. The dotted lines indicate the main drainage area at points A, B and C. 
Author-produced version of the article published in Hydrological Processes, 2012, 26(22), 3393-3404.

The original publication is available at http://onlinelibrary.wiley.com

DOI:10.1002/hyp.8422
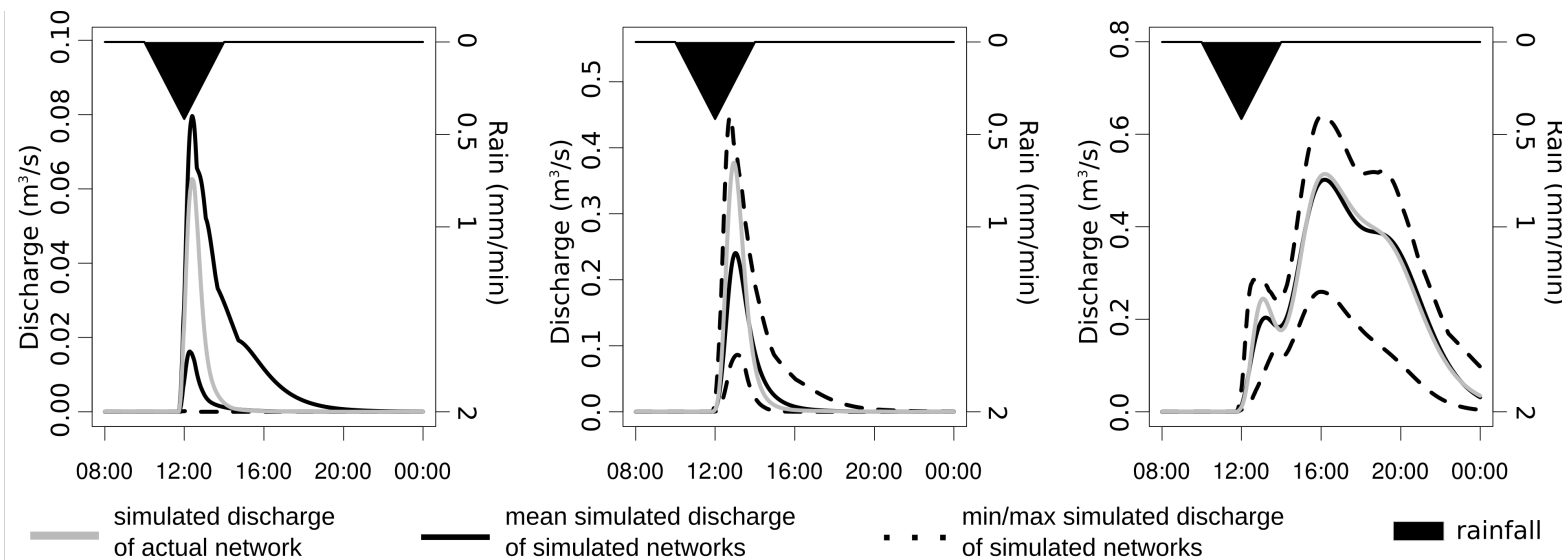
of actual network

mean simulated discharge of simulated networks

$\mathrm{min} / \mathrm{max}$ simulated discharge of simulated networks

Figure 7: Hydrographs along the invariant main downstream network. The variability among hydrographs was high, although the shape of the actual hydrograph was well simulated. 
Author-produced version of the article published in Hydrological Processes, 2012, 26(22), 3393-3404.

The original publication is available at http://onlinelibrary.wiley.com

DOI:10.1002/hyp.8422

Roujan subcatchment outlet Bourdic catchment outlet
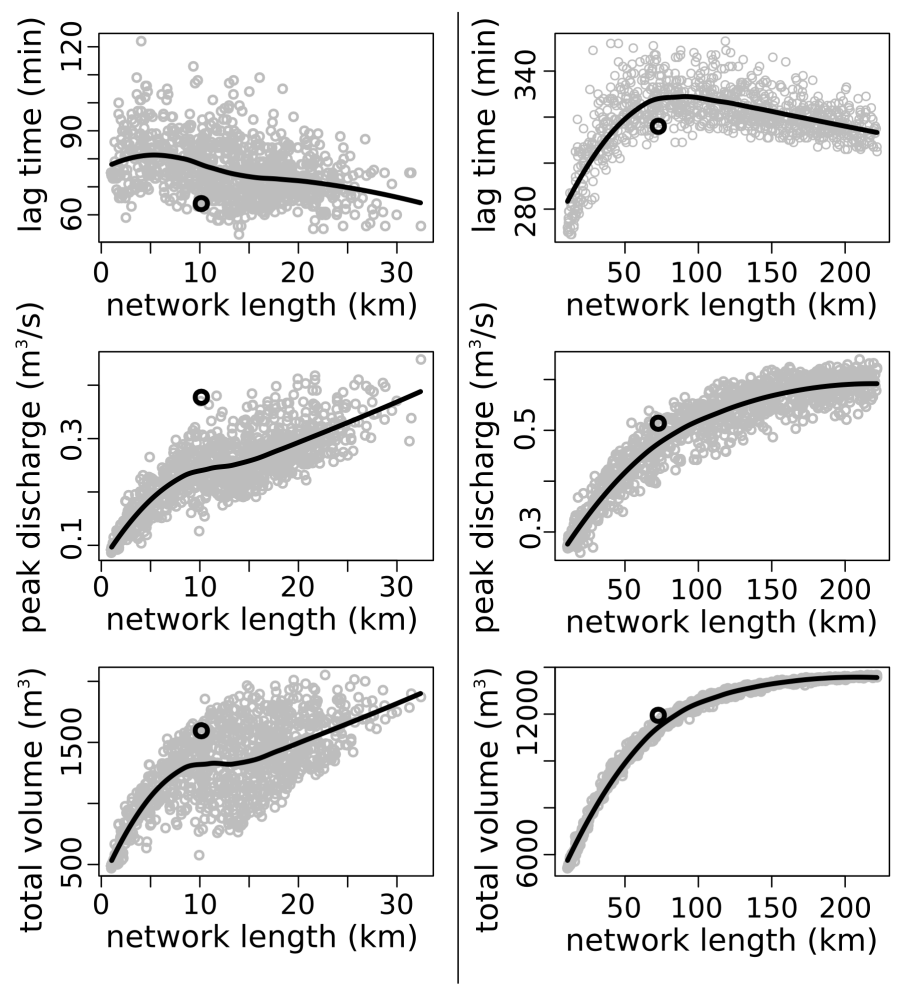

Simulated networks

- Actual network - Trend line

Figure 8: Relationship between runoff metrics and network lengths. The runoff metrics were correlated with the drainage network length at both the subcatchment and at the catchment scales. The variabilities in network metrics were higher at the subcatchment scale. 
Author-produced version of the article published in Hydrological Processes, 2012, 26(22), 3393-3404.

The original publication is available at http://onlinelibrary.wiley.com

DOI:10.1002/hyp.8422

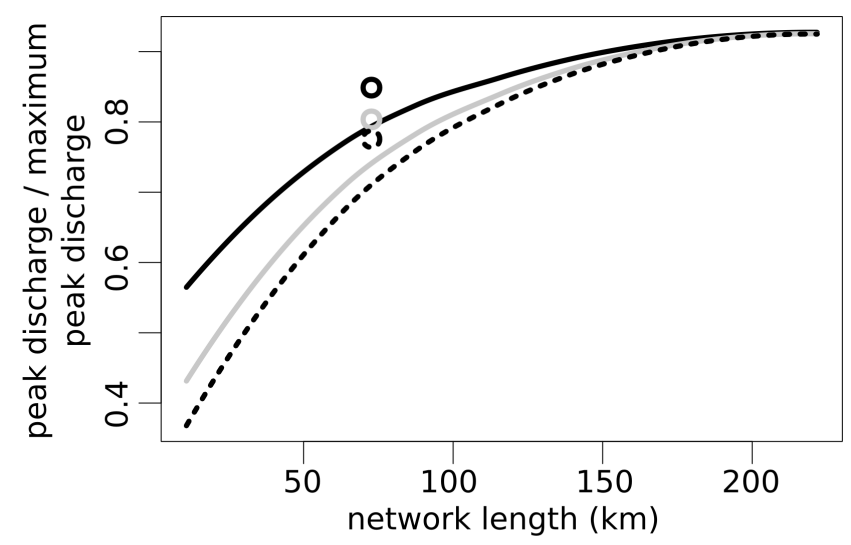

actual value / trend line for simulated values

$$
\begin{aligned}
& \text { o/— } 60 \mathrm{~mm} \text { in } 4 \text { hours } \\
& / 1-50 \mathrm{~mm} \text { in } 4 \text { hours } \\
& : 1 . .30 \mathrm{~mm} \text { in } 2 \text { hours }
\end{aligned}
$$

Figure 9: Relationship between peak discharge and network length for three different rain events. 
Author-produced version of the article published in Hydrological Processes, 2012, 26(22), 3393-3404.

The original publication is available at http://onlinelibrary.wiley.com

DOI:10.1002/hyp.8422

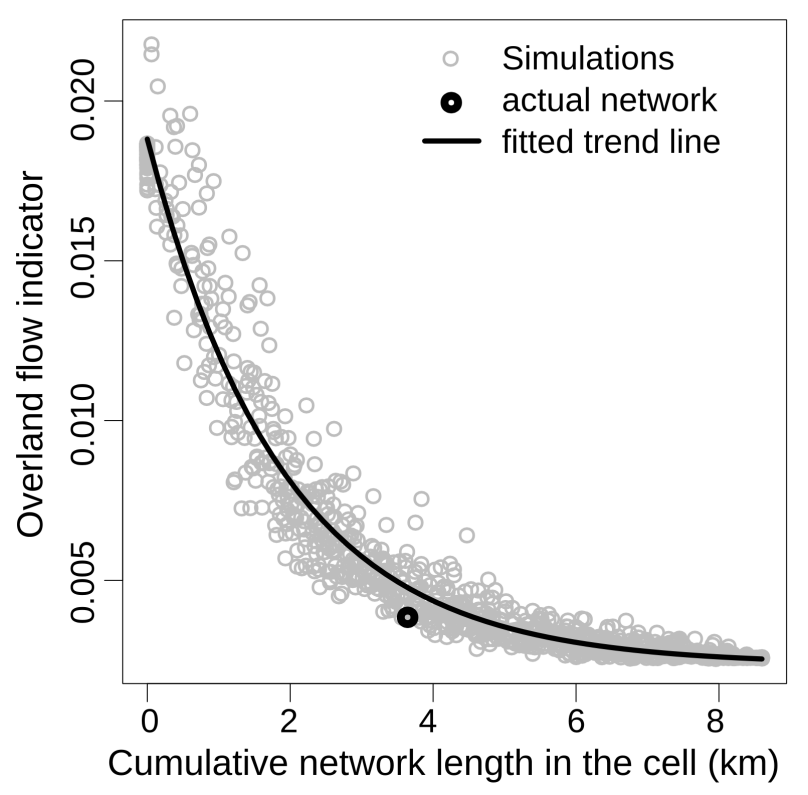

Figure 10: Relationship between the overland flow indicator value and the network length for a given cell. 
Author-produced version of the article published in Hydrological Processes, 2012, 26(22), 3393-3404.

The original publication is available at http://onlinelibrary.wiley.com

DOI:10.1002/hyp.8422
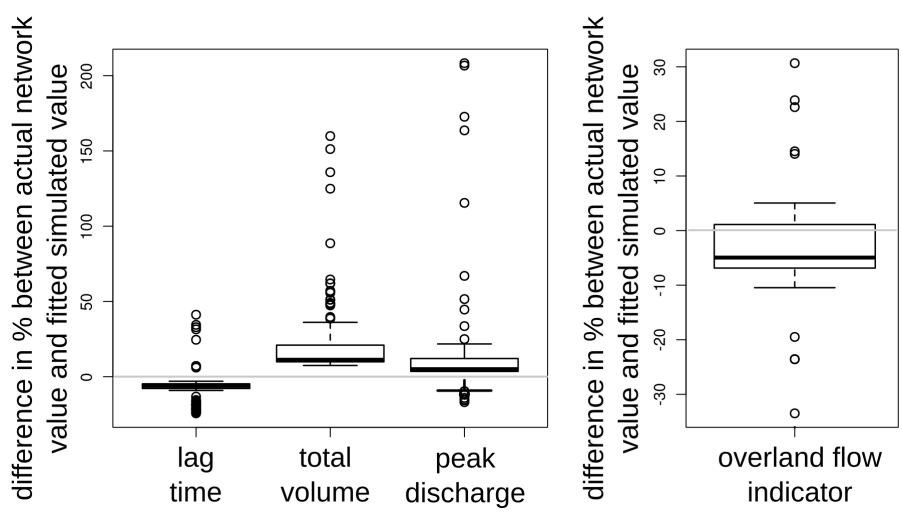

Figure 11: Efficiency of the actual network compared with simulated networks. The boxes represent the interquartile range. The whiskers extend to the most extreme data point which is no more than 1.5 times the interquartile range from the box. In comparison to the simulated networks, the lag time was lower and the total volume and peak discharge were higher for the actual network. The overland flow indicator was lower for the actual network. 